\title{
Perception of consultation length in cardiology and its ethical implications
}

\author{
Hernan C. Doval, ${ }^{1}$ Raul Alfredo Borracci, ${ }^{1}$ Victor D. Darú, ${ }^{1}$ \\ Mariano A. Giorgi, ${ }^{1}$ and Marisa Samarelli ${ }^{1}$
}

Suggested citation Doval HC, Borracci RA, Darú VD, Giorgi MA, Samarelli M. Perception of consultation length in cardiology and its ethical implications. Rev Panam Salud Publica. 2008;24(1):31-5.

ABSTRACT Objectives. This study considered whether the time employers allotted to medical consultations in many working environments in Argentina might be inadequate to carry out an interview. The objective was to conduct a survey to gather information on the length of cardiologic medical consultations in Argentina.

Methods. During 2007, a survey was carried out that included 816 cardiologists.

Results. Seventy-six percent of participants said they needed 20 to 30 minutes, and $14 \%$ considered that 15 minutes was sufficient, for an adequate consultation. On the other hand, $64 \%$ reported that their employer required that consultations be done in 10 to 15 minutes, and $86 \%$ cited limits of less than 20 minutes $(P<0.0001)$. This time was inadequate for $60 \%$ of physicians. With regard to ethics, $89 \%$ answered affirmatively that requiring that patients be attended in such a short time could be considered an ethical flaw of the employer; $75 \%$ acknowledged their own ethical flaw when agreeing to conduct the consultation in an inadequate amount of time. When opinions were grouped, $22 \%$ considered that an adequate consultation length was fundamental for a correct patient-physician relationship, $27 \%$ reported that this time depended on "pressures" of the system, 19\% indicated that inadequate consultation length affected the quality of attention patients received, 17\% thought that low fees forced employers to reduce this time with a resulting detriment in quality of care, and $15 \%$ said that consultation length was variable and depended on the patient.

Conclusions. This study showed that $60 \%$ of physicians perceived as insufficient the time their employers allotted for conducting an adequate consultation. Most believed that allotting such a short time for examining patients could be considered an ethical flaw.

Key words Referral and consultation, cardiology, ethics, Argentina.

One of the main resources of health care systems is the time the physician can devote to patients. This time is cru-

\footnotetext{
1 Argentine Society of Cardiology, Buenos Aires, Argentina. Send correspondence and reprint requests to: Raul Alfredo Borracci, Argentine Society of Cardiology, Investigation, La Pampa 3030, $1^{\circ} \mathrm{B}$ Buenos Aires 1428, Argentina; telephone: 54-01147845917; e-mail: investigacion@sac.org.ar.
}

cial in medicine as it allows patients and physicians to interact not only from a technical and scientific perspective but from a human perspective as well, in accordance with the empathy the patient requires. The successive economic crises in the region of Argentina as well as inadequate planning have contributed to the depreciation of the medical consultation. As a result, in order to maintain the same costs, many health systems have shortened the net time of the consultation.

This circumstance has been consolidated by the sanitary authorities of some other countries of the region (1). The same situation exists in Spain and has been the subject of court appeals and review of some deontological rules $(2,3)$. Efficient use of time is one 
of the most appreciated factors in health care management, to the point where most physicians try to see more patients in less time and keep an adequate relationship with patients despite the shortage of this resource (4). Some studies in developed countries found that patients were generally satisfied with the care they received from doctors but often complained that visits were too short (5). The ethical implications of this phenomenon are evident, since an inadequate consultation length would not guarantee the quality of medical attention.

The primary postulate of the study considered that the time slots per consultation allotted by employers in many working environments where cardiologists in Argentina develop their activities could be inadequate for a satisfactory medical interview. This initial idea claimed that the demand of completing a medical consultation in a time period that was shorter than that considered adequate by the physician had ethical implications not only from the professional's point of view but also from the employer's standpoint, which is an aspect seldom considered in discussions on bioethics.

The objective of this study was to carry out a survey to gather information on the duration of cardiologic medical consultations in Argentina and learn opinions about the adequacy of this time and its ethical connotations.

\section{MATERIALS AND METHODS}

During the first half of 2007, a survey was carried out among cardiologists on the consultation length and its ethical implications. It was performed for 2 months, using a form e-mailed to 2400 cardiologists across Argentina. This sample corresponds to the total census of active members of the Argentine Society of Cardiology. They responded to a series of questions that assessed the minimum consultation time that, according to the physician, was necessary to perform a satisfactory interview, the time required by the employer to perform each consultation if the physician was a full-time employee, and, if applicable, the physician's opinion about noncompliance with ethical rules on his or her part and on the part of the employer with regard to accepting or requiring that consultations be carried out in an inadequate time. Finally, the survey allowed for a brief opinion from each of those surveyed on the analyzed ethical aspects. All opinions were evaluated individually in order to group them in clusters.

To investigate the validity of the sample, a descriptive analysis on demographic characterization of the total population of cardiologists and the sample answering the questionnaire was added. The data were processed as qualitative variables and expressed in percentages or means plus $95 \%$ confidence intervals; results were compared by using $\chi^{2}$ analysis or a Student's $t$ test. As the survey had only five questions and its individual purposes focused on different areas, no confidence test was done for validation purposes.

\section{RESULTS}

The survey was answered by 816 cardiologists, approximately one-third of those surveyed. The demographic characteristics of the total population of cardiologists and of those answering the questionnaire are summarized in Table 1. Differences among groups showed that responders were significantly younger than the total population; however, disparities in the length of time practicing as a cardiologist were not found. Nevertheless, the former difference should reveal a potential selection bias. In the same way, the geographic distribution of surveyed cardiologists across Argentina showed a predominance of cardiologists from greater urban districts like Buenos Aires, Cordoba, and Mendoza.

Table 2 compares the 816 cardiologists surveyed and the national distribution of cardiologists. The proportion of cardiologists in our sample was similar to the national distribution in the three largest cities, and there was a deficit in our sample only in Santa Fe.
Overall, there is a significant difference in these distributions $\left(\chi^{2}=52.0\right.$, $P<0.00005)$, so that our results cannot be generalized to all Argentinean cardiologists.

To the question "how much time do you need to carry out a clinical cardiologic consultation to an outpatient?" $76 \%$ of cardiologists answered that between 20 and 30 minutes was necessary, and 14\% considered that 15 minutes was sufficient. On the other hand, when asked "in case you work for a Social Security System that appoints your patients, what demands in terms of time do you have to carry out each consultation?" In $64 \%$ of the cases, respondents stated they were required to perform the consultation in 10 to 15 minutes, and $86 \%$ replied they had 20 minutes or less (Table 3 ). This time requirement resulted in inadequate consultation for $60 \%$ of the surveyed cardiologists.

When asked "do you think that the demand of attending a patient in such a short time could be considered an ethical flaw on the side of the employer?" 89\% of those surveyed responded affirmatively. Likewise, 75\% of the cardiologists acknowledged their own responsibility when they considered that accepting the requirement to attend a patient in an inadequate amount of time was unethical. Of the total 816 answers, 401 cardiologists (49\%) included in the survey their opinion about the duration of the consultation issue. These answers were classified into five clusters: $22 \%$ (88/ 401) considered that the adequate duration of the consultation was crucial to the optimum patient-physician relationship. On the other hand, 27\% (108/401) reported that the time of the consultation depends on the "pressures" of the health system that demands such behavior; 19\% (76/401) said that the inadequate duration of the visit affects the quality of medical attention, and $17 \%(68 / 401)$ said that low fees in particular force them to reduce the duration of consultations, thereby impoverishing the quality of their attention. Finally, 15\% (60/401) said that the consultation length was variable and depended particularly on its char- 
TABLE 1. Demographic characteristics of nonsurveyed and surveyed populations, Argentina, 2007

\begin{tabular}{|c|c|c|c|}
\hline Demographic characteristic & $\begin{array}{c}\text { Nonsurveyed } \\
(n=1584)\end{array}$ & $\begin{array}{l}\text { Surveyed } \\
(n=816)\end{array}$ & $P$ \\
\hline Mean age in years $\left(\mathrm{Cl}_{95}\right)^{\mathrm{a}}$ & $51(40.5-51.5)$ & $45(44.3-45.7)$ & $<0.001$ \\
\hline Male gender & $1175(74.2 \%)$ & $645(79.0 \%)$ & 0.003 \\
\hline \multicolumn{4}{|l|}{ Time as cardiologist } \\
\hline$<16$ years & $633(40.0 \%)$ & 329 (40.4\%) & \multirow{3}{*}{0.269} \\
\hline $16-25$ years & $378(23.9 \%)$ & $215(26.3 \%)$ & \\
\hline$>25$ years & $573(36.1 \%)$ & $272(33.3 \%)$ & \\
\hline
\end{tabular}

${ }^{\mathrm{a}} \mathrm{Cl}_{95}=95 \%$ confidence interval.

TABLE 2. Geographic distribution of cardiologists: comparison of surveyed cardiologists with national distribution, ${ }^{\text {a }}$ Argentina, 2007

\begin{tabular}{lcr}
\hline Geographic distribution & Surveyed $(n=816)$ & National $(n=7370)^{\mathrm{b}}$ \\
\hline Buenos Aires & $427(52.3 \%)$ & $3744(50.8 \%)$ \\
Cordoba & $64(7.8 \%)$ & $560(7.6 \%)$ \\
Mendoza & $48(5.9 \%)$ & $419(5.7 \%)$ \\
Santa Fe & $31(3.8 \%)$ & $856(11.6 \%)$ \\
Rest of provinces & $246(30.1 \%)$ & $1791(24.3 \%)$ \\
\hline a $P<0.00005\left(\chi^{2}\right.$ for $5 \times 2$ contingency table) &
\end{tabular}

b National data were estimated from different sources.

TABLE 3. Comparison of times required for consultation according to the physician and those required by the employer, ${ }^{\text {a }}$ Argentina, 2007

\begin{tabular}{lcccrrrr}
\hline & \multicolumn{7}{c}{ Time, minutes } \\
\cline { 2 - 7 } & 10 & 15 & 20 & 30 & 45 & $>45$ \\
\hline Physician & $16(2 \%)$ & $114(14 \%)$ & $343(42 \%)$ & $277(34 \%)$ & $49(6 \%)$ & $17(2 \%)$ \\
Employer & $228(28 \%)$ & $294(36 \%)$ & $180(22 \%)$ & $65(8 \%)$ & $16(2 \%)$ & $33(4 \%)$ \\
\hline
\end{tabular}

a $P<0.00005$ ( $\chi^{2}$ for $2 \times 6$ contingency table).

acteristics. Representative quotes from the cardiologists' responses are included in the Appendix.

\section{DISCUSSION}

This study showed that $60 \%$ of the surveyed physicians perceived the time their employers allotted to carry out an adequate medical consultation as insufficient. Most of them thought the demand of attending patients in such a short time could be considered unethical from the physician's standpoint as well as from the employers' standpoint.
There is sufficient evidence that managed care systems have significantly reduced the length of the medical consultation and, hence, the autonomy of physicians to manage their time (6-12). One decade ago, in a survey among young physicians, only $32 \%$ responded that they had the freedom to choose the duration time of consultations, which showed a substantial reduction with regard to previous surveys $(13,14)$.

However, despite the fact that many physicians think employers urge them to see more patients in less time, some studies have shown that the growth of managed care between 1989 and 1998 was not associated with a reduction in the length of consultations. Mechanic et al. (4) showed that the average length of medical consultations remained stable between 16 and 22 minutes during those 10 years. Likewise, the analyses of consultations in primary care carried out by the American Medical Association between 1978 and 1994 did not show a reduction in the duration of visits $(15,16)$. In our study, on the other hand, two-thirds of those surveyed answered that they had less than 15 minutes to see each patient. An important aspect to be considered in interpreting these results is that the general dissatisfaction of physicians with regard to the health system in Argentina could have affected their answers to the questionnaires and thus influenced their perception and opinion about the length of consultations, even though it might not have been the main problem.

Factors related to consultation length depend on physicians, patients, and the health system. It has been observed that, in general, older physicians and women doctors tend to spend more time in consultations, as long as the waiting list is not too long (17). Several investigators found that women doctors average more time for each consultation, probably due to increased communication skills and empathy toward patients (18-22). Thus, the proportional growth in the number of women in the medical profession could influence the need for increased consultation length.

On the other hand, Deveugele et al. (6) showed that consultation times tend to shorten as the workloads of physicians increase. When assessing the length of the general medical consultation in different European countries, the same authors found that in Belgium and Switzerland it averaged 15.3 minutes, in Great Britain and The Netherlands it was 9.8 minutes, whereas in Spain and Germany it was 7.7 minutes. These differences have been related to the different health systems in the countries being compared.

The reduction in the length of consultations appears contradictory with 
the increased complexity of medicine, particularly in some specialties such as cardiology. One aspect to consider to justify that the medical consultation should be longer every time is that the case mix of patients could include more complex diseases, with more options for diagnosis and treatment. Similarly, today patients ask more questions, want to be informed, and require more extended explanations about disease prevention (4). Finally, the time the physicians use is crucial to patients' satisfaction and to keep them within the physician's professional practice (23).

On the other hand, the ethical implications of an inadequate time allotment for each consultation are rarely discussed in daily medical care. Public awareness of this idea about the ethical aspects of consultation, which involve not only the physician but also the employer in health care systems, could initiate the necessary debate that would ultimately benefit the patient.

The principal limitation of this study is that the low response rate of the questionnaire and the geographic distribution of surveyed cardiologists prevent one from generalizing the results to medical practices in all of Argentina. However, a comparison between the national distribution of cardiologists in Argentina and the sample of 816 physicians surveyed showed little difference.

Although the study represents only the perception of the surveyed physicians with regard to the length of the consultation and its ethical implications, the country's sanitary authorities could take advantage of this essential information to design public health strategies that involve quality in medical consultation and, ultimately, its value.

This study showed that $60 \%$ of the surveyed cardiologists perceived as insufficient the time their employers allotted them to perform an adequate medical consultation. Whereas the ideal time would be around 20 to 30 minutes, two-thirds of those surveyed actually had less than 15 minutes per consultation. Also, most considered that this demand of attending a patient in such a short time could be considered an ethical flaw on the part of both the physician and the employer.

\section{REFERENCES}

1. Restrepo SY. Código de ética médica y ley de seguridad social. Sociedad Colombiana de Anestesiología y Reanimación. Médico-Legal online. Available from: www.medicolegal. com.co. Accessed 21 May 2007.

2. Central de Deontología, Derecho Médico y Visado. Informe de los médicos de atención primaria pública de España. La masificación y el aumento de la presión asistencial que sufren los médicos de atención primaria. Julio de 2001. Available from: www.diezminutos. org. Accessed 21 May 2007.

3. Tribunal Superior de Justicia de Madrid. El insalud debe motivar la superación del cupo máximo. Available from: www.diezminutos. org. Accessed 21 May 2007.

4. Mechanic D, McAlpine DD, Rosenthal M. Are patients' office visits with physicians getting shorter? N Engl J Med. 2001;344:198-204.

5. Wilson A. Consultation length in general practice: a review. Br J Gen Pract. 1991;41:119-22.

6. Deveugele $M$, Derese A, van den BrinkMuinen A, Bensing J, De Meseneer J. Consultation length in general practice: cross sectional study in six European countries. BMJ. 2002;325:472-7.

7. Bodenheimer T. The American health care system: physicians and the changing medical marketplace. N Engl J Med. 1999;340:584-8.
8. Kassirer JP. Doctor discontent. N Engl J Med. 1998;339:1543-5.

9. Reardon TR. The patient-physician relationship. Vital Speeches Day. 1999;66:114-6.

10. Stone TT, Mantese A. Conflicting values and the patient-provider relationship in managed care. J Health Care Finance. 1999;26:48-62.

11. Mechanic D. Changing medical organization and the erosion of trust. Milbank Q. 1996;74: 171-89.

12. Emanuel EJ, Dubler NN. Preserving the physician-patient relationship in the era of managed care. JAMA. 1995;273:323-9.

13. Hadley J, Mitchell JM, Sulmasy DP, Bloche MG. Perceived financial incentives. HMO market penetration, and physicians' practice styles and satisfaction. Health Serv Res. 1999;34:307-21.

14. Burdi MD, Baker LC. Physicians' perceptions of autonomy and satisfaction in California. Health Aff (Millwood). 1999;18:134-45.

15. Stafford RS, Saglam D, Causino N, et al. Trends in adult visits to primary care physicians in the United States. Arch Fam Med. 1999;8:26-32.

16. Luft HS. Why are physicians so upset about managed care? J Health Polit Policy Law. 1999; 24:957-66.

17. Knight R. The importance of list size and consultation length as factors in general practice. J R Coll Gen Pract. 1987;37:19-22.

\section{APPENDIX}

Quotes from cardiologists' responses.

- "The restraints imposed by the health care system upon the consultation length frustrate the preventive educational function of the medical practice."

- "To shorten consultation length in cardiologic practice not only constitutes an ethical flaw but also could potentially induce medical errors."

- "The adequate patient's office visit duration must be privileged over employers' opinions or restrictions."

- "Since the employer and the health care system impose the conditions, the ethical flaw of attending a patient in a shorter time cannot be attributed to the doctors."

- "In order to properly listen to, examine, diagnose, and teach the patients, consultation time must not be restricted."

- "To shorten the consultation length generates the paradox of increasing costs, for doctors substitute the lack of time with laboratory tests and expensive imaging techniques."
18. Glied S. The treatment of women with mental health disorders under $\mathrm{HMO}$ and fee-forservice insurance. Women Health. 1997;2:1-16.

19. Bernzweig J, Takayama JI, Phibbs C, Lewis C, Pantell RH. Gender differences in physicianpatient communication: evidence from pediatric visits. Arch Pediatr Adolesc Med. 1997; 151:586-91.

20. Cooper-Patrick L, Gallo JJ, Gonzalez JJ, $\mathrm{Vu}$ HT, Powe NR, Nelson C, et al. Race, gender, and partnership in the patient-physician relationship. JAMA. 1999;282:583-9.

21. Roter DL, Hall JA. Why physician gender matters in shaping the physician-patient relationship. J Womens Health. 1998;7:1093-7.

22. Bertakis KD, Helms LJ, Callahan EJ, Azari R, Robbins JA. The influence of gender on physician practice style. Med Care. 1995;33:407-16.

23. Gross DA, Zyzanski SJ, Borawski EA, Cebul $\mathrm{RD}$, Strange KC. Patient satisfaction with time spent with their physician. J Fam Pract. 1998; 47:133-7.

Manuscript received on 1 August 2007. Revised version accepted for publication on 4 March 2008. 
RESUMEN Objetivos. Se analizó si el tiempo asignado por los empleadores para las consultas médicas en centros de trabajo en Argentina es insuficiente. El objetivo fue recopilar información mediante una encuesta sobre la duración de las consultas de cardiología en

Percepción sobre la duración de las consultas de cardiología y sus implicaciones éticas

\section{Argentina.}

Métodos. Se aplicó una encuesta a 816 cardiólogos en 2007.

Resultados. De los participantes, 76\% dijo necesitar de 20 a 30 minutos para una consulta adecuada, mientras 14\% consideró que 15 minutos era suficiente. Por otra parte, $64 \%$ informó que sus empleadores exigían que las consultas se realizaran en 10-15 minutos y $86 \%$ citó límites menores de 20 minutos $(P<0,0001) ; 60 \%$ de los médicos consideraron inadecuado ese tiempo. De los entrevistados, $89 \%$ respondió que exigir que se atienda a los pacientes en ese corto tiempo podría considerarse una falla ética de los empleadores; $75 \%$ reconoció su propia falla ética al aceptar realizar la consulta en un tiempo inadecuado. Cuando se agruparon las opiniones, 27\% manifestó que ese tiempo dependía de "presiones" del sistema, 22\% consideró que realizar la consulta en un tiempo suficiente era fundamental para una correcta relación médico-paciente, 19\% indicó que un tiempo insuficiente de consulta afectaba a la calidad de la atención que recibía el paciente, $17 \%$ pensaba que los bajos honorarios forzaban a los empleadores a reducir ese tiempo con el consiguiente detrimento en la calidad de la atención y 15\% dijo que la duración de la consulta era variable y dependía del paciente.

Conclusiones. Estos resultados muestran que $60 \%$ de los médicos percibían como insuficiente el tiempo que sus empleadores les asignaron para llevar a cabo las consultas. La mayoría consideró que asignar un tiempo tan corto para examinar a los pacientes puede considerarse una falla ética.

Palabras clave Remisión y consulta, cardiología, ética, Argentina.

\section{Ataque cardíaco y accidente cerebrovascular. Prevención}

Esta publicación presenta datos de la eficacia de las intervenciones para la prevención secundaria de la cardiopatía coronaria y la enfermedad cerebrovascular, así como para la prevención de la vasculopatía periférica y la diabetes. También se incluyen en ella recomendaciones clínicas y se identifican las áreas en las cuales se necesita mayor investigación.

El libro está destinado a los profesionales médicos con la responsabilidad de atención de pacientes con ECV en poblaciones y países de ingresos bajos y medianos. Su objetivo es proporcionar orientación general acerca de la eficacia de intervenciones específicas, tanto farmacológicas como sobre comportamientos y hábitos de vida.

\footnotetext{
Adquiera esta publicación por medio de la librería en línea de la OPS: http://publications.paho.org; correo electrónico: paho@brightkey.net; Fax: (301) 209-9789; Oficina de país de la OPS/OMS
}

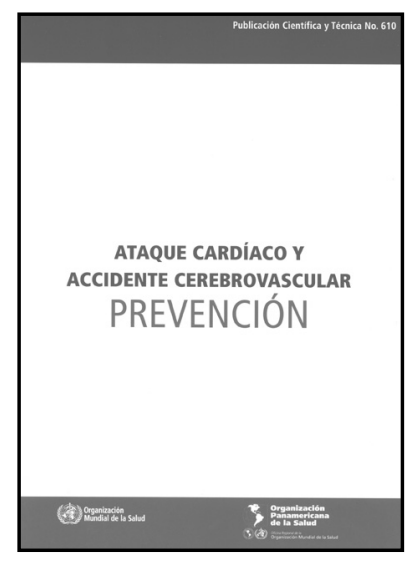

2005, pp., 107

ISBN: 9275316104

US\$ 15.00 en América Latina y el Caribe/ US\$22.00 en el resto del mundo

Código: PC 610 